\title{
Prevalence of Cronobacter spp. in various foodstuffs and identification by multiplex PCR
}

\author{
Filiz AKSU ${ }^{1 *}$, Sema SANDIKÇI ALTUNATMAZ ${ }^{1}$, Ghassan ISSA², Aksem AKSOY ${ }^{3}$, Harun AKSU ${ }^{4}$
}

\begin{abstract}
Cronobacter spp. are opportunistic pathogens isolated from many different type of food and environmental samples and may cause serious health problems and even death in newborns, children and elders. The purpose of the study was to determine occurrence and prevalence of Cronobacter spp. in animal originated food, ready-to-eat food, fruits and vegetables, sold in Istanbul and its vicinity and to perform molecular typing of the isolated agents by multiplex PCR. Analyses were conducted on a total of 219 food samples including 11 confectionary, 50 fruits and vegetables, 52 dairy products, 50 meat and meat products and 56 ready-to-eat food. Suspected isolates were validated by PCR targeted to gyrB gene and multiplex PCR was performed for identification. Overall analyses revealed a prevalence of $5.48 \%$ for Cronobacter spp. in all food products assessed. Prevalence of the bacteria was $9 \%, 1.9 \%$ and $17.8 \%$ in confectionary, dairy products and ready-to-eat food, respectively whereas no bacteria were detected in fruits and vegetables, meat and meat products. Out of a total of 12 isolates determined, 8 (66\%), $3(25 \%)$ and $1(8 \%)$ were identified as C.sakazakii, C.muytjensii and C.malonaticus, respectively and nine isolates belonged to cereal-based balls (meatless cig kofte).
\end{abstract}

Keywords: cereal-based balls (cig kofte); Cronobacter spp.; dairy product; meat product; PCR.

Practical Application: The presence of Cronobacter spp. in ready-to-eat-food can cause a risk of food safety.

\section{Introduction}

Cronobacter spp. are gram-negative, asporogenous, motile bacilli included in the family Enterobacteriaceae. Due to the opportunistic nature of these bacteria they may induce several clinical symptoms in different age groups. High mortality rates were documented especially in the newborns (Garbaj et al., 2017; Iversen et al., 2004; Iversen et al., 2008; Li et al., 2014; Joshi et al., 2014; Hu et al., 2018).

Six species of the genus Cronobacter were indicated to be foodborne pathogens causing diseases. These pathogenic species such as C.sakazakii (formerly known as Enterobacter sakazakii), C.turicensis, C.universalis, C.dublinensis C.malonaticus and C.muytjensii were reported in different studies. C. dublinensis has recently been divided into 3 subspecies: C.dublinensis subsp. dublinensis, C.dublinensis subsp.lausennensis and C.dublinensis subsp.lactaridi. These six species differ from each other in terms of stress tolerance, virulence capacity and antibiotic resistance. C.condimenti was determined as the seventh species but was found to be of no medical significance (Li et al., 2014; Hu et al., 2018; Iversen et al., 2007; Garbowska et al., 2015).

Cronobacter species were frequently obtained from food products such as powdered infant formula (PIF) (Akineden et al., 2017; Caubilla-Barron et al., 2007; Himelright et al., 2002; Weir, 2002; van Acker et al., 2001). However, they may also be isolated frequently from environmental sources like water, soil and vegetables and the food products can be contaminated subsequently by means of vectors such as rodents and flies (Iversen \& Forsythe, 2003; Koluman, 2011; Vojkovska et al., 2016). As in the case of infant foods, the bacteria were isolated from low-water activity foods like flour, spice, cereal, instant soups and dried pasta in various studies (Aksu et al., 2016; Akineden et al., 2015). Still on the other hand, they may frequently be isolated from plant-based foods of high water activity like salad, fruits and vegetables and also foods of animal origin like milk, meat, fish and their products (Li et al., 2014; Garbowska et al., 2015; Mohammed et al., 2015; Lou et al., 2014; Gökmen et al., 2010). Reported studies revealed the occurrence of the bacteria in animal source foods particularly like egg, cheese, fish, chicken, meat products, milk, pork products, milk powder, sausage, shellfish; in plant-based food like barley, biscuit, cereal, coconut powder, squash, kidney-bean, almond, peanut, lentil, instant dried soup, processed vegetarian food, flour of various origins, spice, dried nuts and fruits, rice, dessert, tea, fermented soy bean, tomato, vegetables and salads (Aksu et al., 2016; Gökmen et al., 2010; Beuchat et al., 2009).

High tolerance of Cronobacter spp. to food preservation methods such as drying, acidic $\mathrm{pH}$, heating and osmotic pressure; the property of biofilm formation and the long-term survival of the bacteria on the surfaces during food processing may be listed among the reasons for the occurrence of bacteria 
in various foods and environmental products. Poor hygienic conditions and contaminated tools and equipment may result in the contamination of the food and food ingredients with this type of bacteria (Jaradat et al., 2014).

Research studies have been carried out in Turkey with respect to the presence of Cronobacter spp. in milk, dairy products and infant food; however no studies are available in terms of the occurrence of these microorganisms in ready-to-eat food (delicatessen and cereal-based balls), confectionary, fruits and vegetables, meat and meat products. Therefore, the current study aimed to determine the prevalence of Cronobacter spp. in a variety of ready-to-eat food, meat and meat products, dairy products, fruits and vegetables and confectionary and to achieve species-based molecular identification of these bacteria.

\section{Materials and methods}

\subsection{Sampling}

A total of 219 different types of food products in their original packaging or as in non-packed form were purchased from miscellaneous sales points in Istanbul and its vicinity, using random selection method. The study material consisted of 11 confectionary, 50 fruits and vegetables, 52 dairy products, 50 meat and meat products and 56 ready-to-eat food. The collected materials were submitted to the laboratory under cold storage conditions and assessed for the presence of Cronobacter spp. by conventional methods.

\subsection{Isolation of Cronobacter spp.in the analyzed samples}

Isolation of Cronobacter spp. was performed according to the method (International Organization for Standardization, 2006) modified by Li et al. (2014). Initially, $25 \mathrm{~g}$ of the sample was homogenized in $225 \mathrm{~mL}$ of buffered peptone water (Oxoid) and incubated at $37^{\circ} \mathrm{C}$ for $18 \mathrm{~h}$. Then, $1 \mathrm{~mL}$ of the content was transferred into a test tube containing $10 \mathrm{~mL}$ of modified Lauryl Sulfate Tryptose Broth (Oxoid) and incubated at $42{ }^{\circ} \mathrm{C}$ for $24 \mathrm{~h}$. Followed by the incubation period, the homogenate was streaked on the surface of Chromogenic Cronobacter Isolation Agar (Oxoid) plate by a loop and then the plates were incubated at $42{ }^{\circ} \mathrm{C}$ for $24 \mathrm{~h}$. Suspected colonies appeared as blue-greenish coloring on the agar were purified in Tryptic Soy Agar medium. Various biochemical tests (indole, methyl red, Voges-Proskauer, citrate, oxidase, catalyze and carbohydrate fermentation tests) were run and gram staining was performed on the isolates for the identification of Cronobacter spp. Verified isolates were preserved in EE Broth containing 20\% glycerol and kept at $-80{ }^{\circ} \mathrm{C}$ for further analyses.

\subsection{Genomic DNA Extraction}

The isolates obtained from Cronobacter spp. analysis were incubated in $5 \mathrm{~mL}$ of Tryptic Soy Broth for $24 \mathrm{~h}$ at $37^{\circ} \mathrm{C}$ prior to the extraction process. DNA extraction was carried out according to manufacturer's instructions by using spin column technology based Genomic DNA Purification Kit (Thermo Fisher).

\subsection{Verification and molecular typing of the isolates by Polymerase Chain Reaction (PCR)}

For the identification of Cronobacter spp. by PCR, gyrB gene fragment with a length of $438 \mathrm{bp}$ ( gyrB-F: ATGGATAAAGAGGGCTACAG ve gyrB-R: CGCCTGATTCTTACGGTTAC) was targeted. Followed by pre-denaturation for $5 \mathrm{~min}$ at $95^{\circ} \mathrm{C}$, the amplification process was carried out in 35 cycles: $30 \mathrm{sec}$ at $94^{\circ} \mathrm{C}, 30 \mathrm{sec}$ at $62^{\circ} \mathrm{C}$ and $30 \mathrm{sec}$ at $72^{\circ} \mathrm{C}$, respectively. Elongation was performed at $72^{\circ} \mathrm{C}$ for $10 \mathrm{~min}$ (Chen et al., 2013).

PCR products obtained after amplification were run on a $1.5 \%$ agarose gel in $1 \mathrm{x}$ TAE for $1 \mathrm{~h}$ at 100 volt. Non-toxic, non-mutagen SYBRSafe DNA stain was used for the visualization of the products. The lengths of the amplicons obtained on the gel were assessed with the DNA ladder by using a gel visualization system (BIO RAD Gel Doc "' EZ Imager).

Molecular identification of Cronobacter spp. was conducted by using multiplex PCR Method suggested by Carter et al. (2013) (Table 1). After pre-denaturation for $3 \mathrm{~min}$ at $94^{\circ} \mathrm{C}$, amplification process of the DNA fragments included 25 cycles: $30 \mathrm{sec}$ at $94^{\circ} \mathrm{C}$, $30 \mathrm{sec}$ at $62^{\circ} \mathrm{C}$ and $60 \mathrm{sec}$ at $72^{\circ} \mathrm{C}$, respectively. Elongation step was adjusted to $5 \mathrm{~min}$ at $72{ }^{\circ} \mathrm{C}$ Carter et al. (2013). C.sakazakii (ATCC 29544) and C.muytjensii (ATCC 51329) were used as the positive controls.

Table 1. Primers used for the molecular typing of Cronobacter spp. (Carter et al., 2013).

\begin{tabular}{cccc}
\hline Primer & Oligonucleotide Chain & Length(bp) & \\
\hline Cdm-469R & Species \\
Cdub-40F & GATACATGGCCGATATGCACGCC & 430 & C. dublinensis \\
Cmuy-209F & TTCTTCAGGCGGAGCTGACCT & 260 & C. muytjensii \\
Cmstu-825F & GGTGGCSGGGTATGACAAAGAC & & \\
Ctur-1036R & TCGCCATCGAGTGCAGCGTAT & 211 & C. turicensis \\
Cuni-1133R & GAAACAGGCTGTCCGGTCACG & 308 & C. universalis \\
Csak-1317R & GGCGGACGAAGCCTCAGAGAGT & 492 & C. sakazakii \\
Cmal-1410R & GGTGACCACACCTTCAGGCAGA & 585 & C.malonaticus \\
\hline
\end{tabular}

\footnotetext{
${ }^{a}$ The PCR primer Cdm-469R was used in multiplex reactions with Cdub-40F and Cmuy-209F primers for identifying C. dublinensis and C. muytjensii strains, respectively. ${ }^{\mathrm{b}}$ The PCR primer Cmstu-825F was used in multiplex reactions with Ctur-1036R, Cuni-1133R, Csak-1317R and Cmal-1410R primers for identifying C.turicensis, C. universalis, C. sakazakii ve C. malonaticus strains, respectively.
} 


\section{Results}

In the study, a total of 219 food products were microbiologically analyzed for Cronobacter spp. Twelve isolates were obtained. Prevalence of Cronobacter spp. was estimated to be $5.48 \%$. Prevalences of the bacteria in terms of the type of the food products were $9 \%, 1.9 \%$ and $17.8 \%$ for confectionary, dairy products and ready-to-eat food, respectively. Cronobacter spp. were not detected in fruits-vegetables, meat and meat products. Isolates were molecularly identified to the species level and 8 (66\%), 3 (25\%) and $1(8 \%)$ isolates were found to be C.sakazakii, C.muytjensii and C.malonaticus, respectively. The number of the analyzed food products and the identified strains were given in Table 2.
Cronobacter spp. positive samples were determined in dehydrated fruit-based leather (traditionally named as pestil) (C. muytjensii) from the confectionary group; in plaited cheese (C. muytjensii) from dairy products; in cereal-based balls (C. sakazakii, C muytjensii, C. malonaticus) and in cooked liver salad (C. sakazakii) from ready-to-eat food.

Gel image of DNA bands obtained from Cronobacter spp. positive isolates by PCR assay was given in Figure 1.

Gel image of Multiplex PCR products for certain Cronobacter spp. isolates identified to the species level was shown in Figure 2.

Table 2. Occurrence and prevalence of Cronobacter spp. in a variety of foods analyzed.

\begin{tabular}{|c|c|c|c|c|c|c|}
\hline Type of food product & $\begin{array}{l}\text { Number of the } \\
\text { samples } \\
(\mathrm{n})\end{array}$ & C. sakazakii & C. muytjensii & C. malonaticus & Positive samples & $\begin{array}{c}\text { Percentage of } \\
\text { positive samples } \\
(\%)\end{array}$ \\
\hline Confectionary & 11 & $-{ }^{\mathrm{a}}$ & 1 & $-{ }^{\mathrm{a}}$ & 1 & 9.0 \\
\hline Fruit and vegetables & 50 & $-{ }^{\mathrm{a}}$ & $-\mathrm{a}$ & $--^{\mathrm{a}}$ & - & 0.0 \\
\hline Dairy products & 52 & $--^{a}$ & 1 & $--^{\mathrm{a}}$ & 1 & 1.9 \\
\hline Meat and Meat products & 50 & $--^{\mathrm{a}}$ & $-{ }^{\mathrm{a}}$ & $--^{\mathrm{a}}$ & - & 0.0 \\
\hline Ready-to eat food & 56 & 8 & 1 & 1 & 10 & 17.8 \\
\hline Total count & 219 & 8 & 3 & 1 & 12 & 5.48 \\
\hline
\end{tabular}

${ }^{-a}$ : not detected

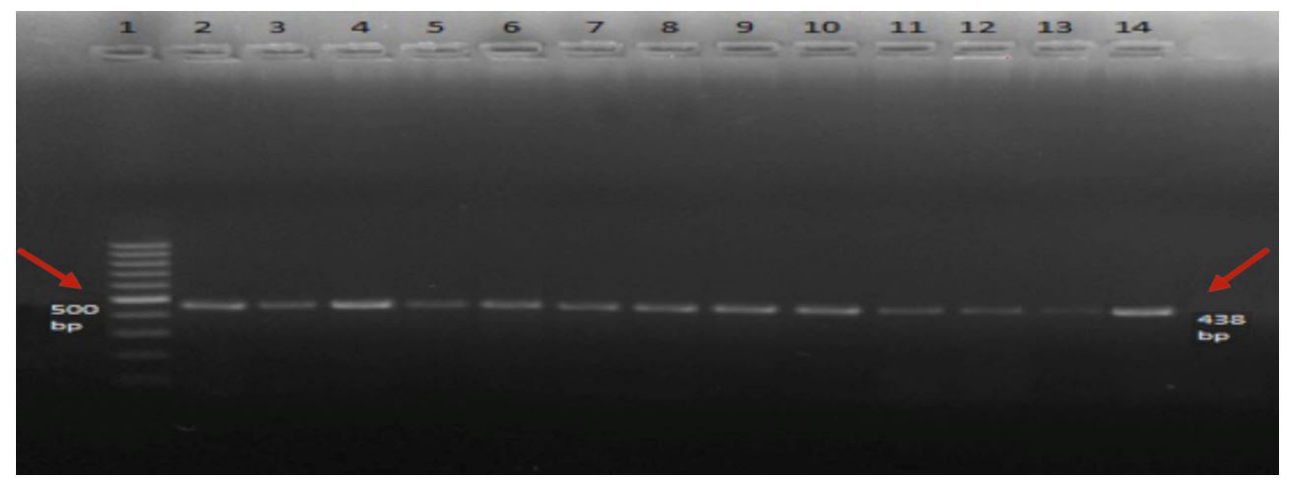

Figure 1. Gel image of 438-bp-long DNA fragments of targeted gyrB gene in Cronobacter spp. positive isolates. $1^{\text {st }}$ loading well: 100 bp DNA ladder; $2^{\text {nd }}-13^{\text {th }}$ loading wells: Cronobacter spp. positive isolates obtained from food samples of different types; $14^{\text {th }}$ loading well: positive control (438 bp C. sakazakii, ATCC 29544).

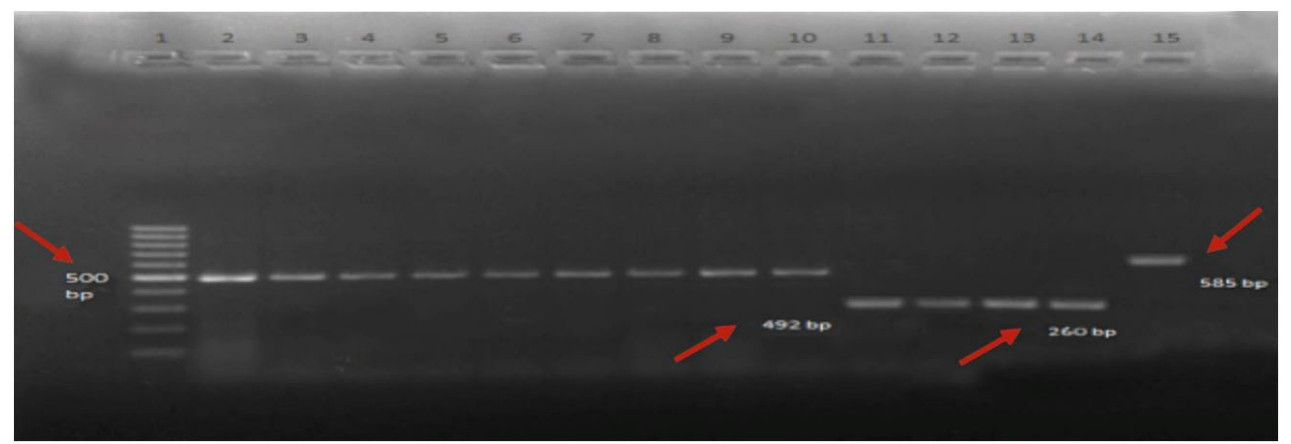

Figure 2. Gel image of some isolates identified to the species level according to their DNA fragments of different lengths by Multiplex PCR assay. $1^{\text {st }}$ loading wells: 100 bp DNA ladder; $2^{\text {nd }}$ loading well: Positive control (492 bp C. sakazakii, ATCC 29544); $3^{\text {rd }}$ to $10^{\text {th }}$ loading wells 492 bp C. sakazakii; $11^{\text {th }}$ loading well: Positive control (260 bp C. muytjensii, ATCC 51329); $12^{\text {th }}$ to $14^{\text {th }}$ loading wells: 260 bp C. muytjensii; $15^{\text {th }}$ loading wells: 585 bp C. malonaticus. 


\section{Discussion}

Since Cronobacter spp. give rise to serious health issues and may even cause high mortality in susceptible individuals like newborns and children, they have been extensively investigated in food products appealing to this age group, like milk powder and infant foods (Gökmen et al., 2010; Yao et al., 2016; Hoque et al., 2010). However, no comprehensive studies are available with respect to the occurrence and prevalence of these bacteria in meat and meat products, fruits and vegetables and ready-to-eat foods in Turkey. For this purpose, 219 miscellaneous food products collected from Istanbul and its vicinity were investigated in terms of occurrence of Cronobacter spp. Suspected isolates were verified by PCR targeted to the specific gene fragment of the bacteria and identification was achieved by multiplex PCR.

In the study, the most noteworthy type of foods in terms of the occurrence and prevalence of Cronobacter spp. were detected to be ready-to-eat food. In this group, 56 food samples, 18 of which were cereal-based balls, were investigated and 10 isolates were determined. Nine (50\%) out of 18 cereal-based ball samples were positive for Cronobacter spp. C.sakazakii, which was the most prevalent species was detected in 7 samples. C.muytjensii was identified in 1 sample and one other sample was positive for C.malonaticus. Cereal-based ball (named as cig kofte) is a local dish, which consists mostly of plant-based foodstuffs like bulgur, (it contains fat free minced meat in some regions), a variety of spice, tomato and red pepper paste, onion, garlic and salt. All ingredients are thoroughly kneaded together and it is consumed uncooked. Despite the lack of sufficient literature information available in terms of the prevalence of Cronobacter spp. in cereal-based balls, microbiological quality of the product has previously been investigated in Turkey. However, the products were found to be of poor quality (especially in terms of total aerobic mesophilic bacteria and Enterobacteriaceae) and it was indicated by several researches that the products were contaminated with numerous microorganisms due to non-hygienic conditions as well as the poor quality of the raw materials (Sancak \& İşleyici, 2006; Elmalı \& Yaman, 2005).

Other product positive for Cronobacter spp. from ready-to-eat food was liver salad which is a cooked side dish served with a variety of spices before consumption. It was considered that the source of contamination in this food product was the spices used. Hence, in the previous studies carried out with respect to prevalence of Cronobacter spp. in spices, Aksu et al. (2016) found $14 \%$ positivity. According to Li et al. (2014) the percentage value of positive products was $4.5 \%$ and Garbowska et al. (2015) reported prevalence rate of $16.7 \%$ for Cronobacter spp. Turcovský et al. (2011) pointed out that particularly plant-based foods contained higher levels of Cronobacter spp. when compared with other types of food products. Likewise, meat products flavored with miscellaneous spices and condiments revealed increased levels of Cronobacter spp. In a study carried out in Korea, prevalence of Cronobacter spp. in Sunsik and Sangsik, which are cereal-based spicy local foods, was found to be $36 \%$ and C.sakazakii was identified in $26.7 \%$ of the isolates (Lee et al., 2012). In this study, prevalence of Cronobacter spp. in raw meat balls which also contained cereal and spice was $50 \%$ and the most prevalent strain was C.sakazakii. Our findings were compatible with those of Lee et al. (2012). As can be seen in many studies with respect to high prevalence of Cronobacter spp. in spice and cereal, spice are demonstrated to be one of the most important sources of contamination in the food which contain these ingredients. Cereal-based balls are food that are widely and fondly consumed in Turkey by different age groups. Schoolchildren also consume this product as snack. It is considered that such contaminants in ready-to-eat foods may give rise to various health problems in immunocompromised individuals.

In the present study, 11 samples were investigated in the confectionary group and Cronobacter spp. (C.muytjensii) was isolated in one product (dehydrated fruit-based leather traditionally named as pestil) with $9 \%$ prevalence. In a similar study, Baumgartner et al. (2009) reported $7.1 \%$ prevalence, which was compatible with our findings. Dehydrated fruit-based leather, which was positive for Cronobacter spp. in this study, is local confectionary which is dried naturally under environmental conditions. The studies carried out with respect to occurrence of Cronobacter spp. in domestic and environmental dust particles supported the idea that the natural drying process might have had increased the risk for contamination (Killer et al., 2015).

In the study, 50 food samples were investigated in fruits and vegetables group and none of them was positive for Cronobacter spp. This finding was compatible with those of Li et al. (2014) and Turcovský et al. (2011) in the studies conducted on fruits/vegetables and fruits, respectively. However, Lee et al. (2012) reported that Cronobacter isolates were obtained from 3 (7.3\%) out of 41 fruit samples and $19(14.8 \%)$ out of 128 vegetable samples. In a similar study by Vojkovska et al. (2016), 38 out of 396 vegetables and 1 out of 49 fruits were positive for Cronobacter spp. in the samples collected from both supermarkets and farms. In the present study, it was considered that the absence of Cronobacter spp. positive products in this type of foods might have been associated with the rather small number of the samples, the selection of samples from different sources and the improvement in fruit and vegetable growing conditions.

In the dairy products group, 52 samples were analyzed and one sample (plaited cheese) was found to be positive for Cronobacter spp. (C.muytjensii) with the prevalence rate of $1.9 \%$. Survival of the bacteria in this product might have been attributed to the insufficient salt concentration in the brine when compared with the equivalent products. Hence, Cronobacter spp. was observed in none of 98 dairy products and 32 cheese samples in a study by Turcovský et al. (2011). Likewise, Heperkan et al. (2017) demonstrated no positivity in 19 cheese samples tested. Our findings were compatible with those of these researches. Pasteurization and fermentation processes applied in these products were shown to constitute biological inhibition technologies. However, it must be considered that there are always risk factors regarding these technologies due to the biofilm formation ability of the bacteria on silicon, latex, polycarbonate, stainless steel, glass and polyvinyl chloride surfaces (Beuchat et al., 2009).

Fifty samples were analyzed in the meat and meat products group and Cronobacter spp. were isolated in none of them. In this category, 25 raw meat and 25 processed meat products (fermented sausage, salami, frankfurter type sausage and pastrami) were 
tested. Researches indicated that these bacteria were found in lower levels in animal-based food than plant-based food. Hence, prevalence of Cronobacter spp. was found to be quite low in meat and meat products in the studies (Wang et al., 2012). However, despite the low prevalence in raw meat, risk factors for contamination were shown to have increased in spiced meat products and thus unfavorable microbiological profile of the spices constituted the source of contamination in a variety of both raw and ready-to-eat food (Turcovský et al., 2011).

\section{Conclusion}

In conclusion, the present study put forward a high prevalence for Cronobacter spp. in plant-based balls that are frequently consumed by different age groups and are available on the market in Istanbul and its vicinity. That the seven out of nine isolates were C.sakazakii; one C.muytjensii and one C.malonaticus, which are the pathogenic strains, indicated that these food products should be taken into account in terms of public health. Occurrence of C.sakazakii and C. muytjensii in spiced cooked liver salad and dehydrated fruit leather, respectively were found noteworthy since these products are ready-to-eat foodstuffs. Particularly, identification of C.muytjensii in one plaited cheese sample was a significant finding. The unfavorable outcomes of the contamination with these species are already associated with the immunocompromised individuals like infants and children however they may give rise to miscellaneous health issues in different age groups, as well. Therefore, it was suggested that the presence of pathogenic agents should be monitored in foods and food manufacturers should take the necessary precautions to provide the food safety from the raw material to the end product under the system of HACCP.

\section{Acknowledgements}

This study was obtained from the project (53226): "Isolation and molecular identification of Cronobacter spp. from various foods" supported by the Research Fund of the University of Istanbul. The first part of the findings from this project were published in Food Sci. Technol, Campinas, 36 (4): 730-736, Oct.-Dec., 2016.

\section{References}

Akineden, Ö., Heinrich, V., Gross, M., \& Usleber, E. (2017). Reassessment of Cronobacter spp. originally isolated as Enterobacter sakazakii from infant food. Food Microbiology, 65, 44-50. http://dx.doi.org/10.1016/j. fm.2017.01.021. PMid:28400018.

Akineden, Ö., Murata, K. J., Gross, M., \& Usleber, E. (2015). Microbiological quality of raw dried pasta from the German market, with special emphasis on Cronobacter species. Journal of Food Science, 80(12), M2860-M2867. http://dx.doi.org/10.1111/1750-3841.13117. PMid:26509868.

Aksu, F., Sandıkçı Altunatmaz, S., Issa, G., Özmen Togay, S., \& Aksu, H. (2016). Prevalence and identification by multiplex polymerase chain reaction patterns of Cronobacter spp. isolated from plant-based foods. Food Science and Technology (Campinas), 36(4), 730-736. http://dx.doi.org/10.1590/1678-457x.16916.

Baumgartner, A., Grand, M., Liniger, M., \& Iversen, C. (2009). Detection and frequency of Cronobacter spp. (Enterobacter sakazakii) in different categories of ready-to-eat foods other than infant Formula.
International Journal of Food Microbiology, 136(2), 189-192. http:// dx.doi.org/10.1016/j.ijfoodmicro.2009.04.009. PMid:19419789.

Beuchat, L. R., Kim, H., Gurtler, J. B., Lin, L., Ryu, J., \& Richards, G. (2009). Cronobacter sakazakii in foods and factors affecting its survival, growth, and inactivation. International Journal of Food Microbiology, 136(2), 204-213. http://dx.doi.org/10.1016/j. ijfoodmicro.2009.02.029. PMid:19346021.

Carter, L., Lindsey, L. A., Grim, C. J., Sathyamoorthy, V., Jarvis, K. G., Gopinath, G., Lee, C., Sadowski, J. A., Trach, L., Pava-Ripoll, M., Mccardell, B. A., Tall, B. D., \& Hu, L. (2013). Multiplex PCR Assay Targeting a Diguanylate Cyclase-Encoding Gene, $c g c \mathrm{~A}$, To Differentiate Species within the Genus Cronobacter. Applied and Environmental Microbiology, 79(2), 734-737. http://dx.doi.org/10.1128/ AEM.02898-12. PMid:23144142.

Caubilla-Barron, J., Hurrell, E., Townsend, S., Cheetham, P., LocCarrillo, C., Fayet, O., Prère, M. F., \& Forsythe, S. J. (2007). Genotypic phenotypic analysis of Enterobacter sakazakii strains from an outbreak resulting in fatalities in a neonatal intensive care unit in France. Journal of Clinical Microbiology, 45(12), 3979-3985. http:// dx.doi.org/10.1128/JCM.01075-07. PMid:17928419.

Chen, W., Ai, L., Yang, J., Ren, J., Li, Y., \& Guo, B. (2013). Development of a PCR assay for rapid detection of Cronobacter spp. from food. Canadian Journal of Microbiology, 59(10), 656-661. http://dx.doi. org/10.1139/cjm-2013-0243. PMid:24102218.

Elmal, M., \& Yaman, H. (2005). Microbiological quality of raw meat balls: produced and sold in the eastern of Turkey. Pakistan Journal of Nutrition, 4(4), 197-201. http://dx.doi.org/10.3923/pjn.2005.197.201.

Garbaj, A. M., Abolghait, S. K., Lawila, A. F., Azwai, S. M., Naas, H. T., Moawad, A. A., Gammoudi, F. T., Barbieri, I., Abureema, S., \& Eldaghayes, I. (2017). Moleculer identification, prevalence and antimicrobial susceptibility profile of Cronobacter spp. cultivated on a chromogenic medium in Libya. Journal of Molecular Microbiology, 1(1), 1-9.

Garbowska, M., Berthold-Pluta, A., \& Stasiak-Rozanska, L. (2015). Microbiological quality of selected spices and herbs including the presence of Cronobacter spp. Food Microbiology, 49, 1-5. http:// dx.doi.org/10.1016/j.fm.2015.01.004. PMid:25846909.

Gökmen, M., Tekinşen, K. K., \& Gürbüz, Ü. (2010). Presence of Enterobacter sakazakii in milk powder, whey powder and White cheese produced in Konya. The Journal of The Faculty of Veterinary Medicine University of Kafkas, 16(Suppl-A), 163-166. http://dx.doi. org/10.9775/kvfd.2010.2801.

Heperkan, D., Dalkilic-Kaya, G., \& Juneja, V. K. (2017). Cronobacter sakazakii in baby foods and food ingredients of dairy origin and microbiological profile of positive samples. Lebensmittel-Wissenschaft + Technologie, 75, 402-407. http://dx.doi.org/10.1016/j.lwt.2016.09.013.

Himelright, I., Harris, E., Lorch, V., \& Anderson, M. (2002). Enterobacter sakazakii infections associated with the use of powdered infant formula-Tennessee-2001. Journal of the American Medical Association, 287(17), 2204-2205. http://dx.doi.org/10.1001/jama.287.17.2204. PMid:11987295.

Hoque, A., Ahmed, T., Shahidullah, M., Hossain, A., Mannan, A., Noor, K., Nahar, K., Ilias, M., \& Ahmed, D. (2010). Isolation and molecular identification of Cronobacter spp. from powdered infant formula(PIF) in Bangladesh. International Journal of Food Microbiology, 142(3), 375-378. http://dx.doi.org/10.1016/j.ijfoodmicro.2010.07.019. PMid:20685000.

Hu, S., Yu, Y., \& Xiao, X. (2018). Stress resistance, detection and disinfection of Cronobacter spp. in dairy products: A review. Food Control, 85, 400-415. http://dx.doi.org/10.1016/j.foodcont.2017.10.014. 
International Organization for Standardization (2006). Milk and milk products-Detection of Enterobacter sakazakii ISO/TS 22964: 2006. Geneva: International Organization for Standardization.

Iversen, C., \& Forsythe, S. J. (2003). Risk profile of Enterobacter sakazakii, an emergent pathogen associated with infant milk formula. Trends in Food Science \& Technology, 14(11), 443-454. http://dx.doi. org/10.1016/S0924-2244(03)00155-9.

Iversen, C., Lane, M., \& Forsythe, S. J. (2004). The growth profile, thermotolerance and biofilm formation of Enterobacter sakazakii grown in infant formula milk. Letters in Applied Microbiology, 38(5), 378-382. http://dx.doi.org/10.1111/j.1472-765X.2004.01507.x. PMid:15059207.

Iversen, C., Lehner, A., Mullane, N., Marugg, J., Fanning, S., Stephan, R., \& Joosten, H. (2007). Identification of "Cronobacter" spp. (Enterobacter sakazakii). Journal of Clinical Microbiology, 45(11), 3814-3816. http://dx.doi.org/10.1128/JCM.01026-07. PMid:17881547.

Iversen, C., Mullane, N., McCardell, B., Tall, B. D., Lehner, A., Fanning, S., Stephan, R., \& Joosten, H. (2008). Cronobacter gen. nov., a new genus to accommodate the biogroups of Enterobacter sakazakii, and proposal of Cronobacter sakazakii gen. nov., comb. nov., Cronobacter malonaticus sp. nov., Cronobacter turicensis sp. nov., Cronobacter muytjensii sp. nov., Cronobacter dublinensis sp. nov., Cronobacter genomospecies 1, and of three subspecies, Cronobacter dublinensis subsp. dublinensis subsp. nov., Cronobacter dublinensis subsp. lausannensis subsp.nov. and Cronobacter dublinensis subsp. lactaridi subsp.nov. International Journal of Systematic and Evolutionary Microbiology, 58(Pt 6), 1442-1447. http://dx.doi.org/10.1099/ ijs.0.65577-0. PMid:18523192.

Jaradat, Z. W., Al Mousa, W., Elbetieha, A., Al Nabulsi, A., \& Tall, B. D. (2014). Cronobacter spp.-opportunistic food-borne pathogens. A review of their virulence and environmental-adaptive traits. Journal of Medical Microbiology, 63(Pt 8), 1023-1037. http://dx.doi. org/10.1099/jmm.0.073742-0. PMid:24878566.

Joshi, S. S., Howell, B. A., \& D’Souza, H. D. (2014). Cronobacter sakazakii reduction by blueberry proanthocyanidins. Food Microbiology, 39, 127-131. http://dx.doi.org/10.1016/j.fm.2013.11.002. PMid:24387862.

Killer, J., Skřrivanová, E., Hochel, I., \& Marounek, M. (2015). Multilocus sequence typing of Cronobacter strains isolated from retail foods and environmental samples. Foodborne Pathogens and Disease, 12(6), 514-521. http://dx.doi.org/10.1089/fpd.2014.1884. PMid:25974656.

Koluman, A. (2011). Isolation and identification of Cronobacter spp. (Enterobacter sakazakii) from different foods. Electronic Journal of Food Technologies, 6(2), 16-19.

Lee, Y. D., Park, J. H., \& Chang, H. (2012). Detection, antibiotic susceptibility and biofilm formation of Cronobacter spp. from various in Korea. Food Control, 24(1-2), 225-230. http://dx.doi. org/10.1016/j.foodcont.2011.09.023.

Li, Y., Chen, Q., Zhao, J., Jiang, H., Lu, F., Bie, X., \& Lu, Z. (2014). Isolation, identification and antimicrobial resistance of Cronobacter spp. isolated from various foods in China. Food Control, 37, 109-114. http://dx.doi.org/10.1016/j.foodcont.2013.09.017.

Lou, X., Si, G., Yu, H., Qi, J., Liu, T., \& Fang, Z. (2014). Possible reservoir and routes of transmission of Cronobacter (Enterobacter sakazakii) via wheat flour. Food Control, 43, 258-262. http://dx.doi.org/10.1016/j. foodcont.2014.03.029.

Mohammed, A. M., Sallam, I. K., \& Tamura, T. (2015). Prevalence, identification and molecular characterization of Cronobacter sakazakii isolated from retail meat products. Food Control, 53, 206-211. http:// dx.doi.org/10.1016/j.foodcont.2015.01.010.

Sancak, Y. C., \& İşleyici, Ö. (2006). A study on the microbiological quality of cig kofte. Journal of Yüzüncü Yil University Veterinary Faculty, 17(1-2), 81-86.

Turcovský, I., Kunikova, K., Drahovska, H., \& Kaclikova, E. (2011). Biochemical and moleculer characterization of Cronobacter spp. (formerley Enterobacter sakazakii) isolated from foods. Antonie van Leeuwenhoek, 99(2), 257-269. http://dx.doi.org/10.1007/s10482010-9484-7. PMid:20640509.

van Acker, J., De Smet, F., Muyldermans, G., Bougatef, A., Naessens, A., \& Lauwers, S. (2001). Outbreak of necrotizing entercolitis associated with Enterobacter sakazakii in powdered milk formula. Journal of Clinical Microbiology, 39(1), 293-297. http://dx.doi.org/10.1128/ JCM.39.1.293-297.2001. PMid:11136786.

Vojkovska, H., Karpiskova, R., Orieskova, M., \& Drahovska, H. (2016). Characterization of Cronobacter spp. isolated from food of plant origin and environmental samples collected from farms and from supermarkets in the Czech Republic. International Journal of Food Microbiology, 217, 130-136. http://dx.doi.org/10.1016/j. ijfoodmicro.2015.10.017. PMid:26513253.

Wang, X., Zhu, C., Xu, X., \& Zhou, G. (2012). Real Time PCR with internal amplification control for the detection of Cronobacter spp. (Enterobacter sakazakii) in food samples. Food Control, 25(1), 144149. http://dx.doi.org/10.1016/j.foodcont.2011.10.037.

Weir, E. (2002). Powdered infant formula and fatal infection with Enterobacter sakazakii. Canadian Medical Association Journal, 166(12), 1570. PMid:12074129.

Yao, K., N'guessan, K. F., Zinzendorf, N. Y., Kouassi, K. A., Kouassi, K. C., Loukou, Y. G., \& Kouamé, P. L. (2016). Isolation and characterization of Cronobacter spp. from indigenous infant flours in public health care centres within Abijan, Cote d'Ivoire. Food Control, 62, 224-230. http://dx.doi.org/10.1016/j.foodcont.2015.10.041. 